PRODUCTION

ENGINEERING ARCHIVES
2015,Vol. 7, No 2, pp 37-39

ISSN 2353-5156

ISSN 2353-7779 (print version)

(online version)

\title{
The idea of leadership maps and managerial grids
}

\author{
Stanisław Borkowski ${ }^{1}$ \\ ${ }^{1}$ Prof. n. techn. i n. ekonom., dr hab. inż., Czestochowa University of Technology, Faculty of Management, Department of Production Engi- \\ neering, e-mail: bork@zim.pcz.pl
}

Abstract: The assessment of the suitability of elements of classic leadership map/ managerial grids for opinion poll was undertaken. 'Dead' measurement points, containing digit 5 as an abscissa or ordinate, were assigned to particular quarters in the leadership grid through switching from the scale of $1 \div 9$ to $1 \div 8$. The structure of assessment of human problem importance and production issues for five enterprises after the change of scale was also presented.

Key words - leadership map, managerial grid, management styles, BOST analysis

\section{Introduction}

The managerial grid is a classic tool for assessment of management styles and manager training. This grid (GRIFFIN R.W. 2007) has been successfully used for training managers to make them employ techniques of improvement of management in order for them to take great care of both people and production at the highest level (9.9).

\section{Management styles}

Based on the nine-point scale of attitude to tasks and people by R.R. Blake and J.S. Mounton (FOŁTYN H. 2009, BORKOWSKI S. 2012), 81 management styles can be identified. Each of them are undoubtedly characterized by a suitable level of orientation towards tasks (production, services) and people. This detailed approach to the analysed results i.e. attitude to tasks and people, has not found many supporters. However, it provides an essential contribution to the development of the science of management styles.

Polish scientists of leadership and management (KuC R.B. 2004, FOŁTYN H. 2009, LiKeR J. K. 2005) argue that, in consideration of characteristics of management, there are four basic management styles (Fig. 1):

- Autocratic management. Work performance is attributed to the organization of working conditions so that the role of the human factor is minimized. These styles are represented by the bottom right part of the grid with the extreme style 9.1 - degenerated, unfriendly autocrat who is focused only on the results.

- Club (democratic) management. Well-thought, care for human needs and maintenance of 'proper relationships' leads to nice, friendly atmosphere and work at a convenient pace. These styles are represented by upper part of the grid with extreme 1.9 style so much oriented to good interpersonal relationships that it is often referred to as a 'club management'. 
- Separated management. Minimum effort necessary to do work is enough to maintain membership in the organization. These styles are located in bottom left part of the grid with 1.1 style within which the leader is not oriented to anything and not necessarily interested in employees and results. There is also a legitimate doubt whether it is actually a management style, although inactivity among the managers might vary.

- Team (integrated) management. The results achieved at work are a result of involvement of the whole team. Interdependence through treating organization goals as 'common goals' is conducive to creation of the relationships characterized by trust and respect. These styles are represented by the upper right part of the grid, which was revealed by the managerial grid and is also referred to as 'integrated style' with relatively strong orientation towards both people and tasks, while style 9.9 is treated as a model style.

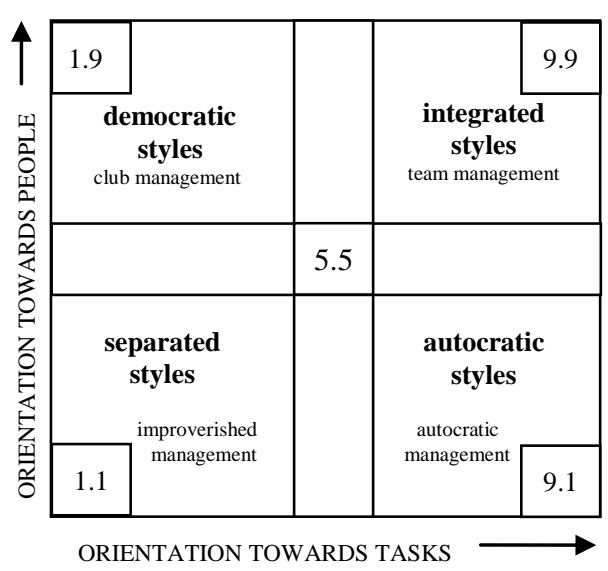

Fig. 1. Groups of management styles with classic names. Source: Fołtyn H. 2009

The study (FOŁTYN H. 2009), however, mentions one style more - balanced (compromise) management. Suitable results in the organization can be achieved through balancing the need for work enforcement and maintaining of staff morale at a suitable level. This style is located in the middle of the grid -5.5 . It is sometimes treated as a compromise style. However, it seems that the central point in the grid indicates that it is sometimes difficult to define unambiguously the style of a particular manager. A similar situation can be observed for the styles vertically and horizontally containing digit 5. In general, it is difficult to determine the group of styles they belong to. Balance of orientation to tasks (x) and people (y) appears not only for $\mathrm{x}=5$ and $\mathrm{y}=5$ but for points $1.1,2.2,3.3,4.4,6.6$, 7.7, 8.8 and obviously 9.9. The problem of the balance is the subject of the analysis in this study (BORKOWSKI S., KNOP K. 2009).

Analysis of the structure from Figure 1 reveals that there are actually nine areas, while the areas marked 1.1, 9.1, 5.5, 1.9, 9.9 were described. Remaining fields, between separated and democratic, democratic and integrated, integrated and autocratic, autocratic and separated are 'dead' fields, without description and interpretation, although it can be noted that they are a compromise between two styles of management. For researchers, results marked with the coordinates: .5, 2.5, 3.5, 4.5, 5.6, 5.7, 5.8, 5.9, 6.5, 7.5, 8.5, 9.5, 5.1, 5.2, 5.3, 5.4 and, to some extent, 5.5 cause huge problems with interpretation of management style. In quantitative comparison, of 81 measurement points, in 17 points (21\%) the terms are unclear and are an ineffective element of scientific investigations.

\section{Structure of Importance of Human Problems and Production Issues Af- ter Reduction in Scale Range}

Figure 2 presents the structure of importance of human problems in five enterprises. As results from the analysis of the pie charts show, the lower assessments were not made, whereas for S915 enterprise, the „8” note also did not appear (Fig. 2d). It is a good harbinger of the proposed change - the rise in share of extreme notes, i.e. „1” and „8” did not occur. However, it should be noted that for S96 (Fig. 2a), note „2” took, with the note „3”, first place in the range of importance, which suggests that grouping of results in terms of these assessments was made. Analysis of the share of other notes, „4” (16.1\%) and „5” (17.9\%) explains this situation. It turns out that grouping the results near a low assessment of importance of human problems does not result from the change in scale, but this concurrence is typical of a specific enterprise (S96).

The result for the data presented in Figure 2 is the managerial grid. Quantitative characteristics of distribution of the results in the managerial grid is presented in Table 1 (Luszniewicz A., SŁABY T. 2008, 
NAWOJCZYK M. 2002, OSTASIEWICZ S., RUSNAK Z., SIEDLECKA U. 1999, PUŁASKA-TURYNA B. 2008).

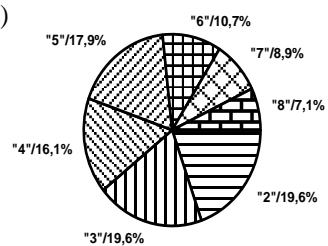

c)

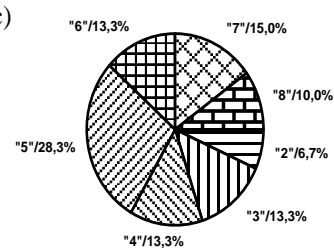

e)

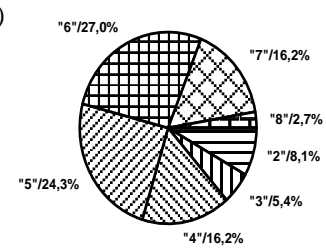

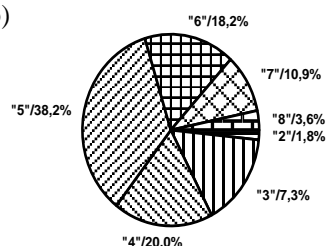

d)

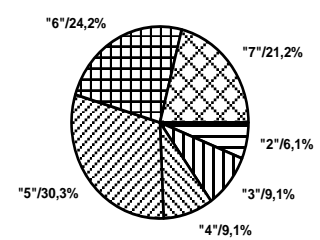

Fig. 2. Structure of Importance of Human Problems (SL) in enterprises: a) 596 , b) $S 98$, c) $S 911$, d) $S 915, e)$ S916.

Source: own study

Table 1. Distribution of the results in managerial grid

\begin{tabular}{|c||c|c|c|c|c|}
\hline \multicolumn{1}{|c||}{$\begin{array}{c}\text { Management } \\
\text { styles }\end{array}$} & \multicolumn{5}{c|}{ Denotation of enterprise } \\
\cline { 2 - 6 } & $\mathbf{S 9 6}$ & $\mathbf{S 9 8}$ & $\mathbf{S 9 1 1}$ & $\mathbf{S 9 1 5}$ & $\mathbf{S 9 1 6}$ \\
\hline \hline Integrated & 25,0 & 49,1 & 36,7 & 36,4 & 64,5 \\
\hline Autocratic & 35,8 & 18,2 & 20,0 & 12,1 & 21,6 \\
\hline Separated & 19,6 & 10,9 & 13,3 & 12,1 & 8,1 \\
\hline Democratic & 19,6 & 21,8 & 30,0 & 39,4 & 5,8 \\
\hline
\end{tabular}

As results from the characteristics demonstrate, the features of management typical of autocratic style of management (35.8\%) can be observed in the enterprise S96. In the enterprise S98, integrated management prevails (49.1\%). This management style is characteristic of the object S911. The advantage of human problems over the importance of production issues occurs for S915 (39.4\% for democratic style). An overall advantage of integrated management style can be observed for the object S916 with the opinions confirmed by as many as $64.5 \%$ of the respondents.

\section{Summary}

The in-depth analysis of the existing structures of leadership maps was made in consideration with equivalence of the results and the possibility of division into four quarters containing an equal number of measurement points. The decision was made on exchanging a popular scale of 1 to 9 point for 1 to 8 . The results of the investigations did not reveal that after this 'reduction' of the scale an accumulation of extreme notes, i.e. „1” and „8”, occurred.

\section{References}

1. BoRKOWSKI S. 2012. Zasady zarzadzania Toyoty w pytaniach. Wyniki Badań BOST. PTM. Warszawa.

2. BORKOWSKI S., KNOP K. 2009. Statistical analysis of initial data for determination of managerial grid. Chapter 6. In: Toyotarity. Styles of management. Borkowski S., SHevTsova O.J. (ed.). Publisher Yurii V. Makovetsky. Dnipropetrovsk.

3. Borkowski S., Pieszczoch D. 2009. Concepts of Leadership Maps and Managerial Grid. In: Toyotarity. Styles of Management. Borkowski S., Shevtsova O. J. (ed.) Yurii V. Makovetsky. Dnipropetrovsk.

4. FoŁTYN H. 2009. Praca współczesnych menedżerów. Wydawnictwa Naukowe Wydziału Zarządzania Uniwersytetu Warszawskiego. Warszawa.

5. GRIFFIN R.W. 2007. Podstawy zarzadzania organizacjami. PWN. Warszawa.

6. KUC B.R. 2009. Od zarządzania do przywództwa. Wydawnictwo Menedżerskie PTM. Warszawa.

7. LIKER J. K. 2005. Droga Toyoty. 14 zasad zarzadzania wiodacej firmy produkcyjnej świata. MT Biznes. Warszawa.

8. LUSZNIEWICZ A., SŁABY T. 2008. Statystyka z pakietem komputerowym Statistica PL. Teoria i zastosowania. C.H. Beck. Warszawa.

9. NAWOJCZYK M. 2002. Przewodnik po statystyce dla socjologów. SPSS Polska. Kraków.

10. Ostasiewicz S., RusnaK Z., SiedleckA U. 1999. Statystyka. Elementy teorii i zadania. Publisher Akademia Ekonomiczna im. Oskara Langego. Wrocław.

11. PuŁaska-Turyna B. 2008. Statystyka dla ekonomistów. Difin. Warszawa. 